\title{
КОМОРБИДНЬЕ РАССТРОЙСТВА У БОЛЬНЫХ ШИЗОФРЕНИЕЙ, ЗЛОУПОТРЕБЛЯЮЩИХ КАННАБИНОИДАМИ (ОБЗОР ЛИТЕРАТУРЫ)
}

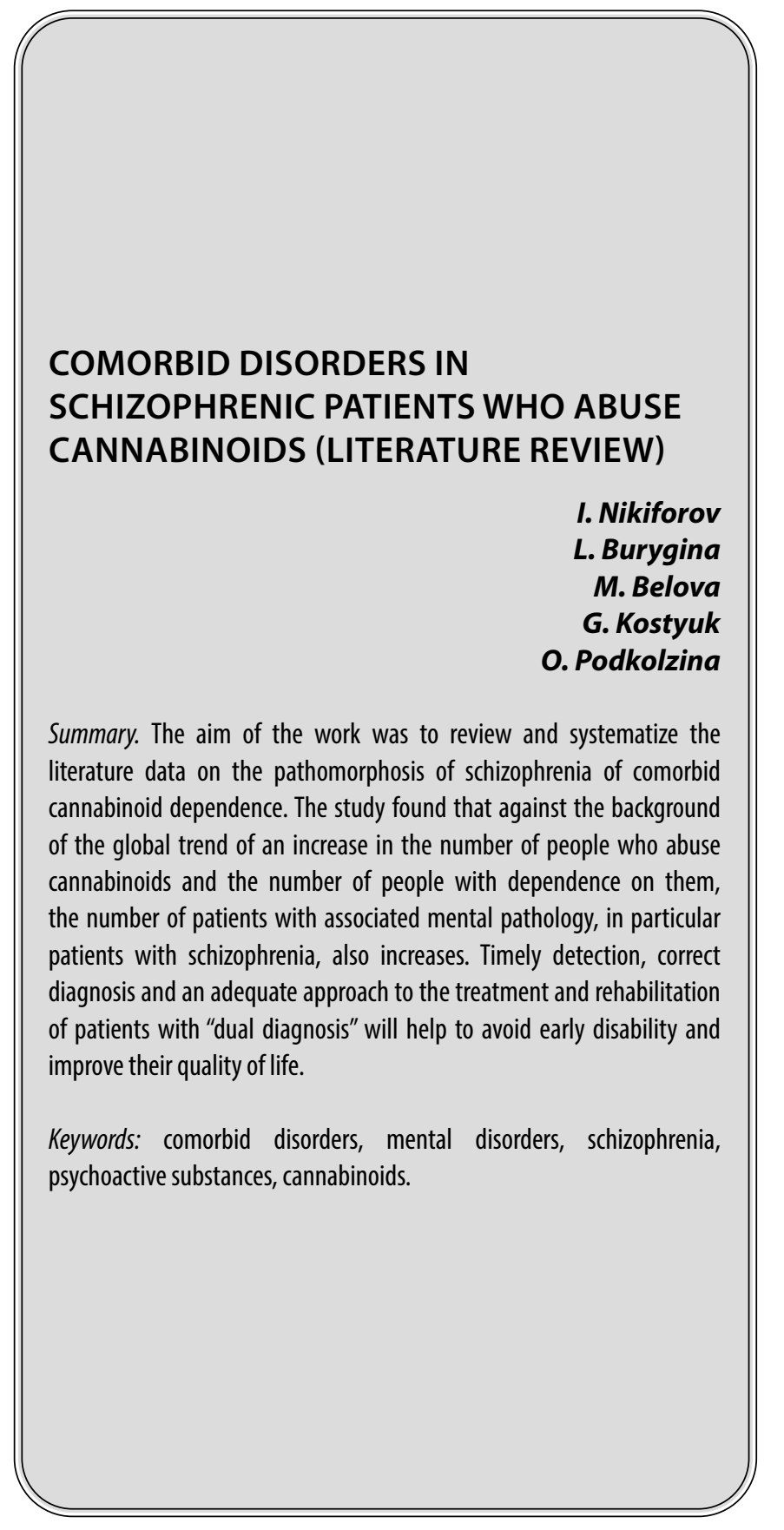

$\mathbf{P}$ аспространенность психических расстройств у пациентов, употребляющих психоактивные вещества значимо больше, чем у остального населения. Установлено, что более 50\% потребителей ПАВ имели минимум ещё одно психическое расстройство. У $26 \%$ это была эмоциональная лабильность, у $28 \%$-страх,
Никифоров Игорь Анатольевич

Д.м.н., профессор, Академия постдипломного образования «Федеральный научно-клинический чентр специализированных видов медицинской помощи и медицинских технологий Федерального медико-

биологического агентства» narkolog.ipk@mail.ru

Бурыгина Лариса Андреевна

Главный врач, Психиатрическая клиническая больница № 4 им. П. Б. Ганнушкина Департамента здравоохранения города Москвы

Белова Майя Юрьевна

Заместитель главного врача по организачии стационарной помощи, Психиатрическая клиническая больница № 4 Департамента здравоохранения города Москвы; Психиатрический стачионар им. В. А. Гиляровского

Костюк Георгий Петрович

Д.м.н., профессор, Главный врач, ГБУз

«Психиатрическая клиническая больница № 1 им. Н. А. Алексеева Департамента здравоохранения города Москвы»

Подколзина Ольга Николаевна Ординатор, Академия постдипломного образования «Федеральный научно-клинический чентр специализированных видов медицинской помощи и медицинских технологий Федерального медико-

биологического агентства»

Аннотация. Целью работы стали обзор и систематизация литературных данных патоморфоза шизофрении коморбидной каннабиноидной зависимости. В ходе исследования установлено, что на фоне общемировой тенденции увеличения числа лиц, злоупотребляющих каннабиноидами, и числа лиц с зависимостью от них увеличивается и количество больных с сопряженной психической патологией, в частности больных шизофренией. Своевременное выявление, правильная постановка диагноза и адекватный подход к лечению и реабилитации пациентов с «двойным диагнозом» помогут избежать ранней инвалидизации и улучшить качество их жизни.

Ключевые слова: коморбидные расстройства, психические расстройства, шизофрения, ПАВ, каннабиноиды.

у 18\%-антисоциальные изменения личности, а у 7\% выявлена шизофрения [1].

Почти 50\% больных шизофренией имеют коморбидные расстройства, вызванные употреблением ПАВ. Каждый третий пациент наркологической клиники имеет 
сочетанную психическую патологию [2]. Наиболее часто встречается сочетание шизофрении и каннабиноидной зависимости.

Шизофрения является самым распространённым психозом, достигая в популяции частоты $1 \%-1,5 \%$. Каждый год в мире регистрируется 2 млн. новых случаев заболевания [3,4].

При изучении патогенеза шизофрении установлено, что по сравнению со здоровыми людьми у этих больных увеличен синтез дофамина, его содержание в синапсах, объём высвобождаемого дофамина в ответ на воздействие некоторых ПАВ, что наиболее выражено не в лимбическом, а в ассоциативном стриатуме. Эти аномалии дофаминовой системы выявлены еще до развития психоза.

У больных шизофренией, не получавших медикаментозного лечения, выявлено значительное уменьшение объема таламуса и хвостатого ядра. Таламус имеет большее количество связей с ассоциативным стриатумом и префронтальной корой, и нарушения в любой из этих структур влияет на работу всей сети целиком. Гиппокамп и амигдала могут опосредованно влиять на эту сеть.

Избыточная стимуляция $\mathrm{D}_{2}$ рецепторов в ассоциативном стриатуме способствует развитию психотической симптоматики. Нарушение поступления информации В стриатум через таламус, префронтальную кору или другие регионы может, как спровоцировать дисфункцию ассоциативного стриатума, так и дополнить её $[4,5]$.

При шизофрении желудочки мозга расширены, объем ткани самих долей уменьшен. Чем выраженнее эти явления, тем тяжелее у пациентов расстройства мышления и слуховые галлюцинации. ПЭТ сканирование обнаруживает повышенную активность в височных долях, особенно в гиппокампе, отвечающего за ориентацию и сверхкратковременную память.

Регистрация электрофизиологических параметров мозга показывает, что большинству больных шизофренией свойственно чрезмерно повышенное реагирование на повторяющиеся внешние раздражители и более ограниченную по сравнению со здоровыми людьми способность устранять ненужную информацию [6].

Заболевание шизофренией создает у больных предрасположенность к развитию состояний зависимости, которые относятся к аддиктивным расстройствам. Распространенность аддикций среди больных шизофренией выше, чем в общей популяции населения. Каждый третий пациент нарколога имеет сочетанную психическую патологию [2] и число коморбидный психической патологии растёт.
Марихуана является широко распространенным наркотикам в Европе и США, особенно среди молодых людей. Минимум 7 млн. человек в США используют марихуану минимум раз в неделю. Минимум 65 млн. взрослого населения Европы (20\% жителей в возрасте от 15 до 64 лет) заявили об употребление каннабиса хотя бы раз в своей жизни [7].

По данным ООН около 4\% населения мира злоупотребляют каннабиноидами, из них 2/3 являются лицами работоспособного возраста, а 10\% - молодёжь. Употребление наркотических препаратов, содержащих каннабиноиды, становится распространенным явлением во всём мире. $62 \%$ случаев наркотизации населения начинается именно с каннабиноидов. От $10 \%$ до $60 \%$ случаев их употребляют подростки ежедневно, а от $2 \%$ до 7\% - студенты [8].

Во всем мире коноплю употребляют приблизительно 180 млн. человек [9].

Конопля содержит более 70 каннабиноидов, часть из них биологически активна. Более действующим считается транс-D-9 тетрагидроканнабиол (TГK) от числа коего находится в зависимости положительный результат. Однако суммарный результат воздействия конопли обусловливается абсолютно всеми активными каннабиноидами. Они отвечают за появление эйфории, высокую общительность, а кроме того, высокую сенсорную чувствительность [10].

В экспериментальных изучениях назначение ТГК вызвало дозозависимое ухудшение процессов обучения, снижение внимания и памяти [10]. Определено нарушение абстрактного мышления, сокращение его продуктивности, изменение ассоциативных процессов, обобщения, не целенаправленность мыслительных процессов с потерей смыслового компонента [11].

Большие дозы ТГК, в особенности вводимые внутривенно, порождали временные психотические состояния, включая паранойю и галлюцинации. Риск формирования психоза увеличивался при увеличении интенсивности использования конопли [12].

При рассмотрении 9 из 12 проспективных изучений была обнаружена достоверная взаимосвязь употребления каннабиноидов и повышения риска развития психотических признаков либо психотического расстройства [13].

В минувшие годы существенно увеличился интерес к присутствию имеющейся взаимосвязи между потреблением каннабиноидов и психическими проявлениями. Возникновение в минувшие десятилетия сильнодей- 
ствующих сортов каннабиноидных элементов, новых форм синтетических препаратов, а кроме того, препаратов комбинированного вида (каннамиметиков и меткатионов) проявило существенное воздействие на темп развития зависимости. Установлено более 100 наименований синтетических каннабиноидов.

Значительная токсичность современных алкалоидов конопли приводит к снижению продуктивности рабочей памяти, механизмов активной фильтрации информации, формирования автоматизации исполнения заданий [14], увеличению количества пациентов с двойными диагнозами, различными по собственной клинической характеристике психотическими проявлениями, стремительным нарастанием психоорганического состояния, а в последующем - к учащению резидуальных полиморфных психозов $[11,15]$.

Синтетические аналоги тетрагидроканнабинола (ТГК) владеют более значительным психотическим потенциалом по сопоставлению с природными.

Среди психических нарушений при употреблении спайсов выделены депрессия, панические атаки, эйфория, двигательная стереотипия, зрительные и вербальные галлюцинации, деперсоналиация [16].

Синтетические каннабиноиды способны вызывать эпиприпадки, что объясняется тем, что спайс демонстрирует комбинацию разных, иногда никому не известных ПАВ [17].

Среди потребителей каннабиноидов известен синдром дефицита внимания и гиперактивности. Присутствие его у детей считается предиктором раннего начала использования ПАВ [18].

При изучении патогенеза воздействия каннабиноидов на ткани головного мозга ученые сосредоточили внимание на то, что потребление ТГК приводит к увеличению освобождения дофамина в стриатуме [19], возникновению постсинаптической сверхчувствительности к дофамину [20].

Определено, что натуральный ТГК считается частичным агонистом каннабиноидных рецепторов, а синтетические - полными агонистами [21], что разъясняет более высокий психотический потенциал последних.

Токсическое действие синтетических каннабиноидов реализуется посредством возбуждения пресинаптических СВ-1-гетерорецепторов, расположенных на пресинаптических мембранах нейронов иной химической модальности. Возбуждение СВ-рецепторов приводит К модуляции (экзоцитозу) нейротрансмиттеров-ами- нокислот (ГАМК, глутамат, аспартат, глицин), биогенных аминов (норадреналин, дофамин, серотонин), ацетилхолина, нейро-пептидов. По этой причине изменения активности эндоканнабиноидных систем отражается на процессах синаптической пластичности, нейротрансмиссии, обучения и памяти [22].

Особенно опасно воздействие каннабиноидов на незрелый мозг подростков и может приводить к необратимым повреждениям в эндоканнабиноидной системе и сбою нейротрансмиттерной функции [23], что влечёт остановку психосоциального развития. У потребителей синтетических каннабиноидов установлено уменьшение объема гиппокампа [24] и нарушение связи белого вещества в мозолистом теле [25].

Злоупотребление ПАВ шире распространено среди индивидов с психическими нарушениями, чем среди здоровых лиц и, сходным образом, у потребителей ПАВ чаще, чем у других людей, выявляются различные психические расстройства. Высокая распространенность аддиктивных расстройств у пациентов психиатрической клиники, существенно превышает популяционные показатели.

Распространенность злоупотребления ПАВ у больных шизофренией варьирует в пределах 40-60\%.

Повышенный риск злоупотребления ПАВ при шизофрении связан с такими факторами как: мужской пол, молодой возраст, низкий уровень образования, высокая импульсивность и склонность к поиску ощущений. Но эти факторы неспецифичны для употребления ПАВ [26].

В городе Болонья (Италия) 25\% больных шизофренией употребляют марихуану, а в городе Боулдере (США) - 90\%. Коэффициент текущего злоупотребления ПАВ в разных выборках американцев с шизофренией колеблется от $30 \%$ до 40\% против 15\% в общей популяции. [27].

У лиц с шизофренией в 5 раз чаще встречаются случаи употребления различных ПАВ, чем в общей популяции. Несмотря на снижение уровня курения табака среди населения в целом от 70 до 90\% пациентов с шизофренией продолжают курить [28].

По сравнению с пациентами, у которых диагностировано единственное психическое расстройство или расстройства, связанные с употреблением ПАВ, пациенты с коморбидными расстройствами подвержены более высокому риску отсроченного диагноза, более тяжелым психопатологическим симптомам, меньшей приверженностью к лечению, более слабым эффектам лечения, 
более серьёзным нарушениям социального функционирования, увеличению частоты поступлении в отделение неотложной помощи, более высокой распространенности соответствующей соматической патологии, частым суицидальным мыслям, безработице, бездомности, вовлечению в эпизоды насилия или преступного поведения [29].

Лица, страдающие шизофренией и коморбидной каннабиноидной зависимостью подвержены нарастанию эмоционального дефицита и снижению активности в целом. В качестве особенностей и ремиссий у данного контингента отмечено исчезновение интересов, хобби, потребности в общении, друзьях. При объективно сохранной трудоспособности почти половина этих пациентов не работает. Около 40\% этих больных с трудом выполняют простейшие виды домашнего труда. Налицо тенденция хронизации процесса со стойкими бредовыми идеями религиозного содержания и выраженным апато-абулическим синдромом [30].

В Датском исследовании было показано, что любое употребление ПАВ лицами с шизотипическим расстройством, было связано с развитием шизофрении с частотой 16,3\% после 2-х лет наблюдения и 33,1\% после 20 лет наблюдения. При этом расстройстве и употреблении каннабиса коэффициент конверсии шизотипического расстройства в шизофрению соответствовал 58,2\%. Помимо канабиса наибольшее влияние на развитие шизофрении оказывали расстройства употребления амфетаминов и опиоидов [31].

Злоупотребление каннабиноидами и алкоголем значительно увеличивает риск возникновения шизофрении, даже через 10-15 лет после постановки диагноза наркомании или токсикомании [32].

Анализируя результаты большого метаанализа Консорциума психиатрической геномики [33] предположили, что коморбидность между шизофренией и расстройством потребления психоактивных веществ частично обусловлена общей полигенной ответственностью. Эта общая ответственность в наибольшей степени соответствует общему риску расстройств, связанных с употреблением психоактивных веществ, а не конкретному риску отдельных расстройств, связанных с употреблением психоактивных веществ, и усиливает свидетельства размытости границ между шизофренией и расстройствами, связанными с употреблением психоактивных веществ.

Среди психотических расстройств в результате употребления синтетических каннабиноидов длительностью до 1 месяца описаны психозы с делириозной симптоматикой, шизофреноподобные психозы с мономорфной (в виде вербального галлюциноза или бреда) и полиморфной (вербальный галлюциноз, идеаторный вариант психического автоматизма, бред символического значения) клинической картиной, в единичных наблюдениях - с психотической манией. Психозы с длительностью течения более 1 месяца требуют дифференциальной диагностики с параноидной шизофренией либо шизоаффективным расстройством [34].

Ряд авторов прямо утверждают, что возможность существования каннабиноидного психоза, отличного от шизофрении является сомнительной [35].

Риск развития шизофрении у пациентов с психозами, индуцированными каннабиноидами, составляет 46\% [36].

Течение шизофрении с коморбидной наркотической патологией отличается более выраженной прогредиентностью с увеличением частоты обострений, сопутствующих употреблению ПАВ инфекционных и соматических заболеваний, случаев агрессивного и аутоагрессивного поведения [37]. Клиническая картина приступов характеризуется большой резистентностью к психофармакотерапии.

Люди с шизофренией и сопутствующей зависимостью имеют более раннее начало шизофрении, чем те, кто не имел сопутствующей зависимости.

Сопутствующие психотические расстройства связаны с целым рядом неблагоприятных последствий, включая усиление психотических симптомов, ухудшение режима лечения, насилие, жилищную нестабильность и бездомность, сопутствующие инфекционные заболевания, плохое управление денежными средствами, частое пользование услугами скорой медицинской помощи [38].

Согласно данным [39], аддиктивные расстройства у больных шизофренией являются вторичным патологическим процессом. Феноменологический спектр патоморфоза шизофрении образует субпсихотическую основу (атипичные субдепрессивные, неврозоподобные и психопатоподобные расстройства), на которой формируются осевые синдромы зависимости от психоактивных веществ. К основным особенностям синдрома патологического влечения к ПАВ у больных шизофренией относятся: стойкая сверхценность, аффективное напряжение, связанное со стадией шизофренического процесса; нарушение критики к злоупотреблению ПАВ и самооценки, в виде полной анозогнозии к шизофреническому процессу и частичной - к наркологическому заболеванию. В активной стадии шизофренического процесса актуализация ПВ обусловливалась атипичным субдепрессивным аффектом, тревожным компонентом, 
неврозоподобной симптоматикой в рамках подострых приступов.

Адезактуализация ПВ происходила за счет появления параноидной или онейроидной симптоматики. На стадии ремиссии актуализация ПВ происходит на фоне психопатоподобной симптоматики в рамках дефицитарных проявлений, дезактуализацияПВ - при формировании качественных ремиссий или нарастании выраженности негативной симптоматики в виде формирования апато-абулического дефекта. По результатам клинико-биохимического анализа у больных шизофренией определяются два варианта развития аддикции. Первый - экзоформный, аналогичен «неосложненным» формам алкоголизма и наркомании. Второй - эндоформный, имеющий свою шизофреническую специфику. Абстинентное состояние при экзоформном варианте развития аддикции протекает крайне тяжело, с витальным компонентом и тревожно-депрессивным аффектом.

Симптоматика абстинентного синдрома при эндоформном варианте формирования аддикции стерта и показана в основном не длительными астено-депрессивными расстройствами. Выделяются 2 типа сочетания коморбидной патологии. Гетерономный тип сочетания коморбидной патологии проходит на фоне благоприятного, практически неподвижного течения шизофренического процесса либо на фоне неглубоких дефицитарных состояний. Клинические проявления синдрома зависимости в существенной мере сохранены, что гарантирует высокопрогредиентный личностный регресс. Гомономный тип сочетания коморбидной патологии формируется на фоне периодически текущего процесса [1].

Учеными, исследующим патогенез данных расстройств, получены сведения о том, что структуры мозга, которые, как предполагается, отсеивают не принадлежащие к процессу раздражители (к примеру, лобная доля), показывают пониженную активность при ПЭТ-сканировании. В связи с данным с затруднением скрининга сенсорных стимулов посмертные исследования мозговой ткани обнаружили нарушения в мозговых клетках определенного типа - ингибиторных интернейронах. Данные нейроны тормозят деятельность ключевых нервных клеток, не позволяя им реагировать на слишком большое число входящих сигналов. Подобным образом, они защищают мозг от перегрузки сильным потоком сенсорной информации, прибывающей из находящейся вокруг среды. В мозге больного шизофренией число «химически связных» интернейронов либо нейромедиаторов (в большей степени это гамма-аминомасляная кислота (ГАМК)), высвобождаемых данными интернейронами, уменьшено, откуда следует, что роль торможения, нацеленная на устранение перегрузки мозга, выполняется менее результативно. Отличия в функционировании данных нейронов, по-видимому, ведут к переменам в мозговых клетках, высвобождающих нейромедиатор дофамин. Ролью дофамина ученые, изучающие шизофрению заинтересовались уже давно, так как определенные психоактивные средства (такие как, каннабиноиды) увеличивают высвобождение дофамина в стриатуме и формируют эффект постсинаптической сверхчувствительности к дофамину $(19,20)$, что может вызывать психозы, напоминающие шизофрению, а психоактивные средства, блокирующие либо ослабляющие его воздействия, результативны при излечении психозов. Дофамин увеличивает чувствительность клеток мозга к раздражителям. Как правило подобная обостренная чувствительность может быть полезна, увеличивая уровень осознания человеком обстановки в периоды нервно-психического усилия либо опасности, однако для больного шизофренией, чей мозг и без того находятся в состоянии повышенной активности, вспомогательное влияние дофамина может быть условием, который ввергнет его в психоз. Из этих исследовательских сведений вытекает, что при шизофрении прослеживается недостаточная регуляция мозговой работы интернейронами, вследствие чего мозг слишком реагирует на множественные сигналы, прибывающие из окружающей среды, и владеет недостаточной способностью отсеивать нежелательные раздражители. Проблема эта усложняется из-за уменьшения размера височных долей мозга, где, как правило, совершается процесс обработки сенсорных входных сигналов; в следствии чего человеку становится еще труднее адекватным образом реагировать на новые раздражители [40].

Выдвинуто несколько гипотез, объясняющих значительную частоту распространенности зависимости от ПАВ среди больных шизофренией. Возможно отметить 4 основные: гипотеза накапливания условий риска, гипотеза самолечения, диатезно-стрессовая гипотеза и гипотеза нарушений в системе позитивного подкрепления.

Согласно первой гипотезе, больные шизофренией принадлежат к группе риска аддикций так как у них больше, нежели в популяции, прослеживается низкий социальный, когнинтивный, образовательный уровни и, как результат, низкоквалифицированная работа либо безработица, бедность. У них чаще появляются психические травмы. Зачастую они воспитываются в дисфункциональных семьях. Они чаще делаются жертвами насилия и оказываются в ситуации, где доступны наркотики, что приводит к формированию зависимости чаще, нежели в популяции.

Согласно второй гипотезе, больные шизофренией применяют ПАВ для облегчения болезненных признаков 
либо ликвидации побочных эффектов психофармакотерапии.

Распространённой считается диатезно-стерессовая гипотеза, которая постулирует формирование психоза либо усугубление ранее существующей шизофрении под влиянием ПАВ у лиц, имеющих нейробиологическую склонность к формированию психических расстройств.

Согласно следующей гипотезе разрегулированность дофаминовых мезокортиколимбических путей головного мозга, порождающая симптоматику шизофрении, одновременно сдерживает нейрофункциональную активность в системе позитивного подкрепления. Регулярный прием ПАВ приводит к сокращению выраженности данной дисфункции и дает возможность больным шизофренией получать больше удовольствия от собственной жизнедеятельности [41].

Несколько исследователей сосредоточивают внимание на роли глутаматной системы в развитии зависимости от ПАВ у больных шизофренией. Считается, что при шизофрении нарушается нормальное подавляющие действие глутаматных связей гиппокампа и префронтальной коры на аккумбентное ядро, что активизирует поведение, нацеленные на отбор активирующего вещества и, в конечном итоге, ведет к формированию зависимости. Имеется данные [42], показывающие, что введение ПАВ (кофеин, амфетамин), повышает уровень глутамата в области вентральной покрышки и в аккумбентном ядре, что увеличивает дофаминовую трансмиссию в лимбической системе и отмеченным ядре и подобным образом опосредует положительный подкрепляющий эффект ПАВ $[26,41]$.

\section{Выво $\triangle \mathrm{b}$}

Почти половина больных шизофренией имеют расстройства, вызванные употреблением ПАВ. Наиболее частая коморбидная патология связана с приемом каннабиноидов. Особенно быстро она развивается при злоупотреблении синтетических препаратов. При си- стематическом приеме высоких доз ТГК возникает риск развития психотических состояний, включая тревожные и аффективные расстройства, бредовую и галлюцинаторную симптоматику, тяжёлые соматоневрологические осложнения, быстрое нарастание психотического состояния. Повышенный риск злоупотребления ПАВ у больных шизофренией связан с такими факторами как мужской пол, молодой возраст, низкий уровень образования, высокая импульсивность и склонность к поиску новых ощущений.

Пациенты с коморбидными расстройствами подвержены риску более раннего начала эндогенного процесса, более тяжелым психопатологическим симптомам, меньшей приверженности к лечению, более слабым эффектам лечения, серьёзным нарушениям социального функционирования, большей распространенностью сомато-неврологической патологии, частым обострением заболевания и суицидальными мыслями, девиантному и агрессивному поведению. Фактор употребления препаратов канабиса является пусковым элементом трансформации шизотипического расстройства в шизофрению. Злоупотребление каннабиноидами увеличивает риск развития шизофрении даже через 10-15 лет после диагностики наркомании. У лиц с коморбидными расстройствами быстрее и отчетливее формируются апато-абулические расстройства со стойкими бредовыми идеями, преимущественно религиозного содержания.

Коморбидность между шизофренией и расстройствами, вызванными употреблением ПАВ обусловлена общей полигенной ответственностью.

Среди психопатологических расстройств в результате злоупотребления каннабиноидами встречаются психозы с делириозной симптоматикой, шизофреноподобные синдромы как с мономорфной, так и с полиморфной симптоматикой.

Ряд авторов утверждает, что возможность существования каннабиноидного психоза, отличного от шизофрении является сомнительной.

\section{ЛИТЕРАТУРА}

1. Афанасьева А. В. Особенности употребления психоактивных веществ больными шизофренией и его влияние на течение шизофренического процесса (обзор литературы). //Украінский Вісник психотерапіі — том 19, вып. 3(68) - 2011. с. 82-85.

2. Красильников Г.Т.; Дресвянников В. Л.; Бохан И. А. Коморбидные аддиктивные расстройства у больных шизофренией. //Наркология 2002, № 6, с. 24-30.

3. Скрипников А.И., Кидонь П. В. Клинические характеристики манифестации параноидной формы шизофрении, сочетанной с употреблением каннабиноидов.//Психиатрия, психотерапия и клиническая психология. 2016, том 7, № 1, с. $22-29$.

4. Kesby J.P. et al. Dopamine, Psychosis and schizophrenia: the widening gap between basic and clinical neuroscience. //Transl. Psychiatry. 2018 Jan31; 8(1):30 doi 10.1038/s 41398-017-0071-9)

5. https://moduniver.com/Medical/Psixology/146.htme MedUniver

6. DHHS/SAMHSA Results From the 2004 National Surrey of Drug Use and health: National Findings. 2004; 1-294. 
7. Каннабиноиды, фармакологические свойства и перспективы их применения в медицине/С.А. Андронати и др.// Вісник психіатріі та психофармакотераnii.— 2012.— № 1.— c. 25-35.

8. United Nations office on Drugs and Crime. World drug report 2015, New York: United Nations, 2015.

9. Per twee R.G. The diverse CB1 andCB2 receptor pharmacology of three plant cannabidiol delta 9 tetrahydrocannabinol and cannabidiol and delta 9 tetrahydrocannabivarin. Br. J. pharmacol 2008; 153: 199215

10. Morrison P. 0. Zois V. McKeown D.A. et al. The acute effects of synthetic intravenous Delta 9 tetrahydrocannabinol on psychosis mood and cognitive functioning psychol Med 2009; 39: 160716

11. Богданов А.С., Психопатологические расстройства у лиц с зависимостью от каннабиноидов. Вопросы Криминологии, криминалистики и судебной экспертизы. 2017, № 1(41) с. 209-214.

12. Marconi A., Diforti M., Lewis C. M. et. al.Meta analysis of the assotciation between the level of cannabis use and risk of psychosis. Schizophr. Bull 2016; 42:1262 9

13. Gage S.H., Hickman M., Zammit S., Association between cannabis and psychosis: epidemiologic evidence Biol. Psychiatry2016; 79:549 56.

14. Ларионова Е. В. Нарушение когнитивных функций и некоторые особенности электрической активности мозга при употреблении каннабиноидов. Журнал высшей нервной деятельности, 2013, Том 63, № 6, с. 643-655.

15. Чухрова М. Г. Пронин С. В., Рыбальчук Н. В., Иванова В. Э. Психические и психосоматические последствия спайсов// Мир науки, культуры, образования.2015. - № 1.—C. 423-426.

16. Kedzior K. K. Laeber L. T. A positive association between anxiety disorders and cannabis use or cannabis use disorders in the general population a meta-analysis of 31 studies. BMC Psychiatry 2014; 14:1 22.

17. Мрыхин В. В. Анцибаров А. В. Дизайнерские наркотики: краткая история, попытка систематизации на примере «спайсов» и «солей» (обзор): КиберЛенинка: https://ciberleninca.ru/article/n/dizaynerskie -narkotiki-kratkaya-istorija-popytka-sistematizatsii-na-primere-spaysov-i-soley-obzor.

18. Chang Z., Lichtenstein P., Larsson H. The effects of childhood ADHD symptoms on early onset substance use: a Swedish twin study J. Abnorm Child. Psychol. 2012; 40:425 35.

19. Murray R.M., Menhta M., Di Forti M. Different dopaminergic abnormalities underlie cannabis dependence and cannabis induced psychosis. Biol. psychiatry 2014; 75:430 1.

20. Головко А. И. Новые запрещенные каннабиноиды. Нейрохимия и нейробиология/ А. И. Головко, А. Г. Софронов, Г.А.// Наркология. — 2010.—№ 7.— - $68-83$.

21. Muller-Vahl K.R., Emrich H. M. Cannabis and schizophrenia: towards a cannabinoid hupothesis of schizophrenia // Expert Rev. Neurother. - 2008. - Vol.8 № 7.- P. 1037-1048.

22. Volkow N.D., Swanson J. M., Evins A. E. et.al. Effects of cannabis use on human behavior, including cognition, motivation, and psychosis a review. JAMA Psychiatry 2016; 73:297 7.

23. Arsenault l., Cannon M., Poulton R. et.al. Cannabis use in adolescence and risk for adult psychosis longitudinal prospective study. BMJ. 2002; 325:1212 3.

24. Yucel M., Lorenzettiv ., Suo C. et.al. Hippocampal harms, protection and recovery following regular cannabis use. TraristPsychiatrty 2016; 6: e710.

25. Rigucci S., Marques T. R., Di Forti M. et.al. Effect of high potency cannabis on corpus callosum microstructure. Psychol. Med. 2016; 46: 84154.

26. Сиволап Ю.П., Янушкевич М. В., Савченков В.А., Двойной диагноз: шизофрения и злоупотребление психоактивными веществами. Неврологический вестник. - 2017. Т. XLIX, вып.2- с. 57-60.

27. https://meduniver.com/Medikal/Psixology/152.htmIMed Univer

28. Alan I. Green et.al. Addiction and schizophrenia: A translational perspective. Schizophrenia Research 194 (2018), 1-3.

29. Langaset. et. al. Коморбидные психические расстройства у потребителей пихоактивных веществ из одной области водосбора — клиническое исследование. BMC Psychiatry 2011; 11:25.

30. Климова И. Ю., Овчинников А. А., Карпушкин А. М. Ремиссия, при параноидной шизофрении, ассоциированной с синдромом зависимости от употребления каннабиноидов//Сибирский медицинский вестник, 2019 (1), с. 15-20.

31. Hjorthj C. Albert N., Nordentoft M. Association of substance use disorder to schizophrenia [published online April 25, 2018] JAMA Psuchiatry. doi: 10 1001/ jamapsychiatry. 2018. 0568

32. Nielsen S. M., Toftdahe N. G., Nordentoft M., Hiorthoi C., Psychol. Med. 2017 Jul; 47(9):1668-1677. doi: 10.107/50033291717000 162. Epub. 2017 , Feb. 7.

33. Hartz S. M., Horton A. S., Oehlert M. et. al., Связь между расстройствами потребления психоактивных веществ и полигенной предрасположенности к шизофрении: Biol. Psychiatry. 2017; 82(10):709. Epub. 2017. Jun 6.

34. Иванова Л. А., Терских Т. В., Татаренко Т. В., Иванова Л. В. Психические расстройства у лиц употребляющих синтетические каннабиноиды (спайсы). Бюллетень ВСНЦ СО РАМН, 2017, Том 2, № 2(114), с. 14-17.

35. Manrique G. E., Zammit S., Dalman C. et.al. Cannabis, schizophrenia and other non affective psychoses: 35 years of follow up of a population based cohort. Psychol. Med. 2012; 42:3218.

36. Niemi-Pynttari J.A., Sund R., Putkonen H. (2013). Substance-induced psychosis converting into schizophrenia: a register-based study of 18,478 Finnish inpatient cases. J. Clin. Psychiatry, 74(1), 94-95.

37. Fergusson D. M., Booden J. M., Horwood L. J., (2006). Cannabis use and other illicit drug use. Testing the cannabis gat away hypothesis. Addiction, 101(4), 556-569.

38. Dixon L. І. Двойной диагноз злоупотребления психоактивными веществами при шизофрении: распространенность и влияние на исходы. Schizophr. Res. 2009; Mar. 1; 35 Suppl: S93-100.

39. Овсянников М. В. Основные типы аддиктивных расстройств у больных шизофренией. Известия вузов. Северо-Кавказский регион. Естественные науки. 2006. № 4., C. 112-115. 
40. https://meduniver.com/Mrdical/Psixology/146.html Med Univer

41. Ерышев 0.Ф., Аркадьев В.В. Сочетание аддиктивных расстройств и шизофрении в аспекте патогенеза и лечения. Журнал неврологии и психиатрии, 5 , 2010, вып.2, с. 67-73.

42. Smelson D. A., Tunis S., L., Nyhis A.W. et. al. Antipsychotic treatment discontinuation among individuals with schizophrenia and co-occurring substance use. J. Clin. Psychopharmacology 2006; 26:666-667.

( ) Никифоров Игорь Анатольевич ( narkolog.ipk@mail.ru ), Бурыгина Лариса Андреевна

Белова Майя Юрьевна, Костюк Георгий Петрович, Подколзина Ольга Николаевна.

Журнал «Современная наука: актуальные проблемы теории и практики»

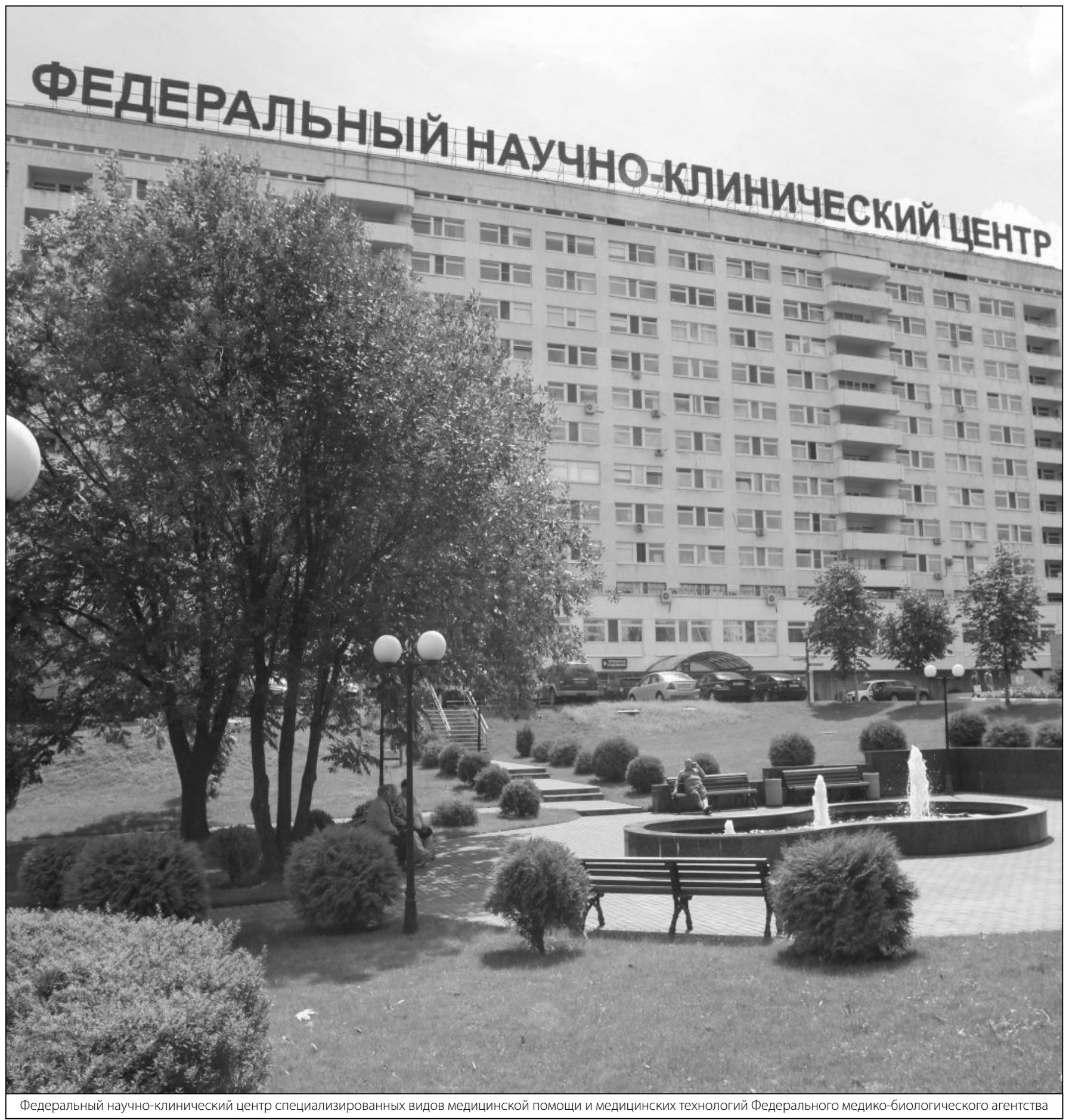

